ferred to. M. Didon was kind enough to allow me to make drawings of them for publication, and in the accompanying figure at $B, C, D$ they are shown side by side with the Eskimos' shaft-straightener described by Dr. Boaz (Franz Boaz, Bull. Am. Mus. Nat. Hist., xv., p. 84, Fig. I17, I901). They are all reduced to the same scale. The larger holes are no doubt intended to be used upon the shafts of javelins or lances; the smaller ones are of an appropriate size for arrows. The largest hole in $A$ is $24 \mathrm{~mm}$. in diameter, in $B 21 \mathrm{~mm}$.; the small hole in $\mathrm{C}$ is only $10 \mathrm{~mm}$.

The most important feature in these implements is the obliquity of the holes; their axes are not perpendicular, but strongly inclined to the face of the implement. Singularly enough, in the more artistic bâton de Commandement of the Magdalenians this refinement is absent, and the hole goes straight through.

The ridges produced by the drill in boring these Aurignacian straighteners are still preserved, except on two opposite sides of the hole, where they have been worn away by use.

Whatever may be the ultimate verdict upon the Magdalenian " bâtons," there can be no question as to the nature of their Aurignacian homologues, since in no essential feature do these differ from the shaft-straighteners of the Baffin's Bay Eskimos described by Dr. Boas.

A similar straightener has been described and figured by Maška from the Kulna cave near Sloup, in Moravia.

Oxford, January 7 .

W. J. Sollas.

\section{The Turkestan Earthquake of January 3-4.}

SOME details of the seismographic and magnetographic records of the great earthquake of January 3 may be of interest to readers of Nature. The three oscillation phases as seen on the seismogram are comparatively large. They commenced suddenly, each with a westward displacement, at IIh. $37 \mathrm{~m}$. , IIh. $44.5 \mathrm{~m}$., and IIh. $48.5 \mathrm{~m}$. p.m. respectively. The large waves (third phase) then continued for 23.5 minutes, producing rapid oscillations of the boom at an average of $35 \mathrm{~mm}$. double amplitude, indicating $14.4^{\prime \prime}$ arc swing of the pillar. But these suffered an early interruption of 5 minutes by an apparent interference of two systems, reducing the amplitude to a minimum at I Ih. $54 \mathrm{~m}$. p.m. The recovery was immediate and sharp, as if by the arrival of a second train of large waves, resembling closely the effect of the initial shock of the first large waves.

The maximum amplitude may have occurred between midnight and 8 minutes after, during which interval the registering light-spot travelled frequently beyond the limits of the camera aperture. But there is a probability that the maximum occurred precisely at midnight; and this is supplied by the mechanical effects upon the three magnetographs, each of which shows a clear maximum oscillation at midnight.

As on former occasions, the bifilar suspension of the horizontal force magnet was much more sensitive to the shakes than the unifilar declination or the vertical force balance. The bifilar responded to the first preliminary earth-tremors, and did not come to final rest for half an hour. Its record shows two groups of lines. The first contains three clear oscillations, marking the beginning, middle, and end of the first tremors. The second group contains five oscillations, including the maximum; and there is a smaller oscillation near the middle of the intervening lull at IIh. 50m. p.m., the commencement of the large waves. The other two curves show only the last group, containing the maximum.

We have therefore on the horizontal force curve oscillations responding to the three initial shocks of the first and second earth tremors, and of the large waves. To these may be added the maximum oscillation at midnight, as probably responding to a sudden increment of the large waves.

The bifilar suspension, being a torsion balance against the horizontal force, is naturally more sensitive to sudden vertical movements of its pillar than to horizontal or slower vertical displacements.

Walter Sidgreaves, S.J.

Stonyhurst College Observatory, January II NO. 2 I.5 I, VOL. 85$]$
As given by the Milne-principle seismograph here, the commencement of the phases of this quake were as follows :-Preliminary : both N. and W. boom, II.34 p.m. Second: N, boom. II.40; W. boom, II.39.5 Principal : N. boom, II.52.9; W. boom, II.52.8.

The actual maxima were:- $-\mathrm{N}$. boom, $110.8 \mathrm{~mm}$. at 11.58 .7 ; W. boom, $131.0 \mathrm{~mm}$. at 11.55 , and $127.6 \mathrm{~mm}$. at II. 58.3 .

There were 30 after-shocks on the $\mathrm{N}$. boom, lasting until 5.II a.m., and 37 on the W. boom, lasting until 5.26.

Woodbridge Hill, Guildford, January 17 .

$$
\text { F. EDWARD NORRIS. }
$$

\section{The Markings of Mars.}

MAY I mention on behalf of my relative, Mr. J. $\mathrm{H}$. Worthington, to whose previous letter M. Antoniadi has replied in Nature of January 5, that he is at present away on an eclipse expedition to the Pacific Ocean, and out of reach of correspondence?

A. M. Worthington.

I The Paragon, Blackheath, S.E., January 17.

\section{Fireball of January 9.}

The Rev. W. F. A. Ellison, of Fethard Rectory, near Waterford, saw a splendid meteor on January 9 at 7 h. $35 \mathrm{~m}$. G.M.T. The apparent path was near Aries and Cetus from $25^{\circ}+3^{\circ}$ to $27^{\circ}-13^{\circ}$. Motion very slow, the whole duration being at least seven seconds.

The flight was directed from the radiant of the January Quadrantids, and it is possible that the fireball formed one of the larger fragments of that stream. But this is uncertain, and another observation is desirable to discover the true radiant. From Cornwall the meteor must have been a very fine object, and must have attracted the notice of many persons, though I have seen no published description of it.

W. F. Denning.

\section{THE ADMISSION OF WOMEN TO THE PARIS ACADEMY OF SCIENCES.}

I $N$ our last week's issue we gave an account of the action taken at the quarterly plenary meeting of the five academies of the Institute of France on January 5 , in relation to the proposal of the Academy of Sciences to elect Madame Curie to the vacancy on the physical section of that body caused by the death of Monsieur Gernez.

A Paris correspondent has sent us a copy of the Temps containing a remarkable letter from M. Darboux, the permanent secretary of the Academy of Sciences, giving the reasons and motives of the academy for their decision. We have not space for the whole letter, which is admirable from start to finish, but M. Darboux insists upon a point missed in all the preceding polemic, which should have an important bearing upon the general question raised by it.

After referring to the magnificent work done by Madame Curie, and the honours which have been showered upon her, he points out that her proposed election as a working member of a busy academy is a matter of great importance, not so much to Madame Curie as to the academy itself.

"Tant de titres, tant de résultats mémorables obtenus dans un si court espace de temps donneraient certes à Mme. Curie le droit de réclamer comme une récompense méritée le siège occupé naguère par son mari. Mais un siège à notre Académie est plus et mieux qu'une récompense. S'il donne une satisfaction légitime et quelques droits, il impose aussi des 
devoirs étendus. Pour examiner à ce point de vue la candidature de Mme. Curie, il est nécessaire que nous rappelions rapidement ici, pour le grand public qui l'ignore quelque peu, le rôle et le fonctionnement de l'Académie des sciences.

"Des cinq Académies qui composent l'Institut de Ftance, elle est peut-être celle qui a la tâche la plus active et la plus lourde. Certes, comme la nôtre, les autres Académies ont des prix à distribuer, moins nombreux et moins variés peut-être; mais le soin de juger des concours et de distribuer des récompenses esi bien loin de former notre principale occupation. Dans ses séances hebdomadaires du lundi, l'Académie écoute avec intérêt les communications, souvent nombreuses, de ses propres membres; mais elle reçoit en outre une foule de travaux, venus de Paris, de la province, de nos colonies, de l'étranger. Il n'est pas rare qu'une de nos séances recueille une centaine de communications ayant les origines les plus diverses. Les comptes rendus de nos séances paraissent le samedi de chaque semaine, cinq jours seulement après la séance; ils contiennent presque toujours de 50 à Ioo pages in $-4^{\circ}$, où se trouvent exposées les recherches les plus neuves, les plus intéressantes. On peut affirmer, sans crainte d'être démenti, que cette publication si rapide, si soignée, constitue le moyen d'action le plus puissant dont dispose aujourd'hui une société savante. J'ajoute que depuis trois ans, notre confrère le prince Roland Bonaparte a confié à l'Académie des sommes importantes, destinées à provoquer et à subventionner les travaux scientifiques les plus méritants.

"Pour accomplir cette tâche féconde, pour distribuer tous ces prix, toutes ces subventions, pour apprécier si rapidement la valeur des communications qui lui parviennent, l'Académie a évidemment besoin de faire appel à toutes les compétences. Où trouvera-t-elle un savant plus autorisé que Mme. Curie pour lui donner un avis sur ces travaux relatifs à la radioactivité, dont le nombre grandit si rapidement?

"D'autre part, ces chercheurs qui peuplent le laboratoire si prospère de Mme. Curie, qui travaillent sous sa direction, devront-ils se résigner à voir leurs efforts et leurs travaux méconnus ou négligés? N'y a-t-il pas un intérêt évident à ce que le chef qui inspire leurs travaux soit admis, comme ses autres collègues de la Sorbonne à les présenter, à les défendre dans les commissions de prix, à les proposer pour des subventions; en un mot, à remplir dans toute son étendue la fonction d'un membre titulaire de l'Académie des sciences?"

"Nous nous contenterons de remarquer, en terminant, que, s'il arrive souvent à notre pays de marcher a l'avant-garde des nations, dans le cas actuel c'est l'étranger qui nous aura donné 1'exemple. $\mathrm{Ne}$ parlons pas, si l'on veut, des distinctions qu'a reçues de ce côté Mme. Curie, bien qu'elle ait été nommée membre actif de quelques-unes des académies que nous avons énumérées plus haut. Mais nous sommes allé dernièrement à Rome, pour y assister aux séances de l'Association des académies, et nous y avons vu la comtesse Ersilia Lovatelli siéger, en qualité de doyenne de la section d'archéologie, à l'académie royale des Lincei, qui joue en Italie le rôle de notre Institut. De même, lorsque nous assistions en 1900 aux fêtes du second centenaire de l'académie des sciences de Berlin, une dame encore, Mme. Elise Wendel, assistait à toutes les cérémonies au titre de membre honoraire de l'académie. Nous pourrions ajouter d'autres exemples; ceux-là suffiront à prouver qu'à l'étranger, on n'éprouve pas les scrupules qui font hésiter quelques-uns de nos confrères."

$$
\text { NO. } 2 \text { I } 5 \text { I, VOL. 85] }
$$

THE SOLAR PHYSICS OBSERVATORY.

$W^{E}$ have received the following Memorial and accompanying signatures and documents from the hon. sec. of the British Science Guild, with a request that we should print it, together with the statement that the Memorial was handed to $\mathrm{Mr}$. Asquith's private secretary by Sir David Gill, K.C.B., F.R.S., president of the Royal Astronomical Society, and vice-president of the British Science Guild, and Sir A. Pedler, C.I.E., F.R.S., hon. sec., and that the Prime Minister was pleased at once to grant the prayer of the memorialists :-

\section{MEMORIAL}

To

The Right Hon. the Prime Minister.

THE Memorial of the undersigned Fellows of the Royal Society and other bodies interested in the welfare of British Science to the Right Honourable H. H. Asquith, Prime Minister, and First Lord of the Treasury.

Shereth

That in i875 the Royal Commission on Scientific Instruction and the Advancement of Science strongly recommended the establishment by the State of an Observatory for Solar Physics.

That in 1879 this recommendation was acted upon by the Government.

That the accompanying letters from the Directors of the Chief Observatories and Meteorological Institutes in Europe and the United States show (I) that the work thus undertaken was of especial importance to the British Empire with its territory distributed all over the globe (2) that the results already obtained are of high value, and promise eventually to lead to the better forecasting of droughts ; (3) that the international character of the work makes it important that it should be carried on in close connection with a Government Department; (4) that a high-level site and free horizon are now essential.

That when a change of site of the Observatory became necessary, the Solar Physics Committee, a Consultative Committee appointed by the Government to advise them on such matters, selected a high-level site at Fosterdown on land purchased some years ago by the War Office, but no longer required by them. The Committee reported that this site fulfils the requirements of modern astronomical research.

And whereas, while we understand that the Solar Physics Committee have not withdrawn their recommendation, the site in question is now advertised for sale on December I3.

We, your Memorialists, therefore pray that the proposed sale of the selected site may be delayed until full inquiry has been made, and until a decision has been arrived at with full knowledge of the questions involved.

And your Memorialists will ever pray.

Lansdowne, Avebury, Rayleigh, Joseph D. Hooker, James Dewar, Iveagh, Lochee, R. B. Clifton, William Ramsay, J. A. Fleming, Fred T. Trouton, Arthur R. Cushny, F. W. Oliver, J. Norman Collie, L. N. G. Filon, E. C. C. Baly, Henry Miers, Augustus Waller, William White, Silvanus Thompson, A. Mostyn Field, J. Wolfe Barry, William Crookes, J. H. Poynting, William Turner, R. A. Sampson, Raphael Meldola, David Bruce, Lauder Brunton, Arthur H. Church, Charles Chree, Dugald Clerk, Wyndham Dunstan, E. H. Griffiths, J. Herschell, W. M. Hicks, Fletcher Moulton, H. E. Roscoe, E. T. Thorpe, William Tilden, E. Ray Lankester, W. H. Dines, G. T. Beilby, C. A. Parsons, John Murray, Arthur A Rambaut, Blyth, Chichester, John Cockburn, Alfred Keogh, J. Herbert Warren, George Burt, George Reid, Baldwin Latham, W. F. Caborne, J. C. Bayard, E. Gold, H. N. Dickson, M. W. C. Hepworth, R. C. K. Lempfert, C. Theodore Williams, P. H. Cowell, Percy Davis, H. H. Walmesley, T. C. Hudson, William Fraser Doak, John A. Sprigge, Harold B. Dixon, James Crichton Browne, H. G. Lyons, George Hartley Bryan, E. Taylor Jones, John Perry, James Stirling, Hugh L. Callendar, P. A. MacMahon. 